\title{
From the Great Wall of China to the Mc Namara Electronic Line: Lessons Learned for Future Barriers
}

\author{
Chi Hieu Hoang
}

\begin{abstract}
In the flow of human history, the emergence of walls between nations/regions was quite common These types of walls partly served the requirement to prevent the flow of migrants or passively defended against the invasion of opposing forces. Appeared from the early of the 3rd century B.C, the Great Wall of China (Great Wall) was the greatest defense work at that era which had accomplished the mission to stop the attack of nomadic tribes to Zhongyuan (Central Plain) for nearly two thousand years, until the fall of Qing Dynasty (1644). In the mid-twentieth century, almost simultaneously Berlin Wall and Mc Namara electronic line were set up when the Cold War was at its most tension. Mc Namara Line was established by the United States based on the combination of the most modern weapons at that time and the massive defense forces, with the aim to isolate the assist of North Vietnam to South Vietnam revolution; however, the Line was broken down after only five years of existence (1967-1972) in the war against a weaker opponent in many aspects - the Vietnamese people. In both cases, the winners were the ones who were blocked. These are examples to prove that all limits could be overcome by humans. From the establishments of the three notorious protective walls in history, this paper is expected to give some suggestions for those who intend to build the protective wall against human collaborations in the modern era.
\end{abstract}

Index Terms - Berlin Wall, Great Wall, Mc Namara Electronic Line, protective.

\section{INTRODUCTION}

In the development process of number, the emergence of barriers between countries/regions was quite popular partly due to the need to protect themselves against the attack of the enemy and to protect their land. In the modern era, besides these purposes, the barriers were also set up to prevent the infiltration of illegal migration to other country's territory. However, not always could these barriers fulfill their missions, even though they were considered as the most effective mean at their time, some examples could be listed as the Great Wall of China (Great Wall), Berlin Wall and Mc Namara Electronic Line.

\section{CONTENT}

The famous Great Wall of China was the typical example of the defensive barrier. In order to prevent the Xiongnu tribes from attacking Zhongyuan (or the Central Plain), after the unification of China in 221 B.C, Quin Shi Huang ordered to

Chi Hieu Hoang is working as Associate Professor, University of Education, Hue University, Vietnam. build the Great Wall. The following dynasties continued to build and develop the wall, increased the length from Bot Hai sea to Tan Cuong desert which lasts for thousand kilometers. It was, in fact, a defensive system rather than just a bare barrier that mainly consist of walls, battlements, parapets, shooting holes, watchtowers. According to the Ming dynasty's rules, the towers would light fire at night and light smokes in the daytime as the signal for the invasion of the enemy. This was an effective way to transmit signal at that time (before the invention of radio transmission)., at the time when war mainly employed infantry and cavalry, walls with $5-7$ metres high made of stones and bricks were considered as the strongest defensive work and could be able to prevent any attack from nomadic tribes. For more detailed information on the Great Wall, please read Julia, L. (2006), The Great Wall: China Against the World, 1000 BC-AD 2000, Great Britain Atlantic Books.

Great Wall symbolizes the separation between to opposing worlds, Huahin civilization, and lower-level nomadic tribes, in this confrontation the defensive side mainly achieved its purposes. However, after nearly 2000 years of existence, the Great Wall was overrun when General Wu Sangui - who was in charge of protecting Shanhai Pass - opened the gate to the Manchu. Since then, the territory of China was expanded, surpassing the limits of Great Wall. The defensive wall fulfilled its mission.

Another typical representative of the kind of protective wall against migration is the famous Berlin Wall which was erected in the Cold War. With the purpose of preventing thousands of people escaping to West Berlin, in 1961 the German Democratic Republic constructed the Berlin Wall which cut off West Berlin and East Berlin. It was not only the wall which divided Germany but also divided into two world systems, two military blocs, two economic systems (Krenz, 2010). However, Berlin Wall could only stop the flow of emigrants but could not stop the desire for country reunification of the German citizen. In addition, it was one of the reasons that made the German Democratic Republic became more backward than its brotherhood at the East side.

By the end of the 1980s, standing in the edge of collapse like other countries in East Europe, many of East German citizen not only wanted to overcome that situation but also erase the symbol of the constraint. In the first week of November 1989, thousands of people had been fled away because they had lost their belief 
that the status quo of German society could be improved. Facing the difficulties in the economic system, renovation and the campaigns and the exodus of emigration were factors that force the leaders of German Democratic Republic to reopen the border with Germany. Right in the night of November 09, 1989, the crowds swarmed the Berlin Wall. The symbol of separation in the Cold War was elapsed.

In Vietnam, facing the situation that Democratic Republic of Vietnam spread its assistance to the war in the South of Vietnam via Ho Chi Minh Trail, "to reduce and make more costly the movement of men and supplies from North Vietnam into South Vietnam for the support of the Viet Cong operations in South Vietnam ("U.S Ground Strategy", 1971). From February 1965, the United States operated Thunder Rolling Operation against the South of Vietnam. However, these air strikes did not bring successful results. Even the America has to acknowledge that "There is no evidence of serious transport problems in the movement of supplies to or within North Vietnam" and "Air attacks almost certainly cannot bring about a meaningful reduction in the current level at which essential supplies and men flow into South Vietnam" ("U.S Ground Strategy", 1971). Therefore, base on the recommendation of Jason group, on September 07, 1967, US Secretary of Defence Mc Namara officially announced the establishment of "a memo proposing an anti-infiltration barrier across the DMZ and the Laotian panhandle as a possible means of arresting troop infiltration from North Vietnam ... that a barrier would make it possible to cease bombing, which was increasingly seen as unsuccessful in breaking Hanoi resolve" (Paullin, 2011). The barrier included two major, closely related subsystems:

(1) A Strong Point Obstacle sub-System (SPOS) (later redesignated DUEL BLADE) stretching across the RVN just below the Demilitarized Zone (DMZ) from the coast to the Laotian border; and (2) An air-supported anti infiltration subsystem stretching westward from the SPOS into Laos to interdict the Ho Chi Minh Trail through central and eastern Laos, by which the enemy supplied his forces in South Vietnam (Henry, 1971).

In this defense system, the United States employed the most up-to-date facilities and weapons available at this time, including those designed for that barrier. Regarding land protection, a system of 17 interconnected bases in the south of DMZ (Doc Mieu, Con Tien, Caroll, Rockpile, Khe Sanh, Lang Vay...), stretching from the coastal areas to the Vietnam-Laos border, created a permanent barrier in"frontier areas" which can prevent any infiltration from the North. It was a system of military bases with firm outposts, multi-layer barbed wire fences and in the middle were the minefields. Sheltered on the fence were the combination of the First Division, Third Marine Division of the United States and the First Infantry Division of the Republic of Vietnam with the support from artillery, tanks, and bombers.

To collect information, the United States launched about 40,000 sensoring devices such as SPIKE BOUY, ACOUBOUY, ADSID, ACOUSIS, Helosid-18,
Arerouy-1/Nbb, Gsid, Mods, ... which were scattered across the forest, where suspected of trail passing. These devices were connected to the central computer in Nakhon Phanom (Thailand) through permanent airplanes in the sky. On the other hand, clearly understood that only weapons and machinery could not bring positive effects in protection, the United States suggested a combination of fixed defense and mobilization forces, by using rangers to collect information from outside of the bases or in the enemy's areas (the North of Vietnam) (Hoang, 2016). In many cases, information collected by the rangers was much more valuable than those from the electronic devices ( $\mathrm{Vu}, 2011)$.

In terms of fire blocking, after receiving the information, the officer in charge of tracking information on the central computer in Nakhon Phanom would choose to rout aircrafts from the nearest airport or from the carrier to implement the attack. It would be base on the targets that the suitable types of aircraft would be chosen, if it was a single small target in plain areas, a helicopter would be used and vice-versa, if the target was bigger or hidden in the forest then bomber would be a better option. On average, the United States used 200 to 400 times of bombers, 10 to 12 times AC-140 special used to attack convoys and around 20 to 30 times of B-52 per day. In general, the United States has employed 240,000,000 Gravel mines; 300,000,000 button bomblets; 120,000 SADEYE cluster bombs; 19,200 acoustic sensors; 68 patrol planes; and possibly 50 aircraft for mine dispensing (Brush, 1996).

To sum up, with Mc Namara electronic lines, for the first time in the war in Vietnam and also in the history of war in the world, the United States launched a high-tech war, combined land forces with electronic warfare and maximized the use of airborne fires, sea fires to prevent the infiltration from the North to the South of Vietnam (Hoang, 2017). It was not just a kind of passive barriers like the Great Wall or Berlin Wall but in fact, a system combined both defense and attack. However, in fact, by employing various means such as opening new routes, developing "secret" trails, actively repairing damaged roads, destroying recording equipment, distracting machines by artificial noises, using aircraft guns and missiles, ... the Democratic Republic of Vietnam has gradually disabled the system. "In the early days, most infiltration on the trail was by human porters walking on narrow paths. By 1972 it contained paved roads capable of handling armored vehicles and a petroleum pipeline" (Brush, 1996). The most obvious evidence was the number of people and the number of materials that the North supported to the South increased annually. In terms of the number of human, in 1968 the supporting number is 141,081; and 1972 was 153,974 . In terms of materials, electronics, on average 114,820 tons were transported to the South each year in comparison to 85,000 tons of 1965-1968 (Vietnam Institute of Military History, 1997). Due to these reasons, after less than one year after construction, the Khe Sanh base-the command center of the electronic line was defeated by the Liberal Forces in the General Strike in 1968, thus made the Line unable to complete like in the intention of Mc Namara and completely failed in the 
Easter Offensive in 1972. Vietnam's bravery and wisdom had won victory over the mighty strength and the latest military achievements of the United States (Hoang, 2017).

\section{CONCLUSION}

Firstly, the first common point to notice that these three barriers were the typical representatives for the preventive and defense purposes. They were built on the foundation of the most modern facilities, even ahead their time in terms of materials, facilities, construction techniques... If the Berlin Wall was just a barrier to prevent their citizen from fleeing from their homeland, the Great Wall of China was prone to a mere defensive work, making the opponents afraid when confronting to the giant wall; then the Mc Namara electronic line was expected to detect any intruder at any forms and then actively attacked with superior firepower with the support of over 100 electronics devices and landmines which had been tested and brought into use by the United States. Many devices which were used in this fence are now developed and used by the United States in building the border wall between the United States and Mexico to prevent illegal immigration.

Secondly, however firm and modern these barriers were, these barriers only could not fulfill their missions of protection but still need the human factor. Regarding the Great Wall, although it has great defensive forces with the best means of communication at this time, when the leaders surrendered, it was easily lost the function. And to the case of Berlin Wall, its protective values could only be brought into use with a large number of patrols equipped with devices to detect escaping people. Or even a modern barrier like Mc Namara Line still need supporting forces. How to collect and process information were the duties of the modern computers, but it was the Officer in charge was the one who decided how to use this information. And at the end, the protective effect largely depended on the capacity of the air forces.

Thirdly, all these three barriers were sooner or later overcome. Ironically, the more modern the work was, the sooner it was defeated (the Great Wall existed for 2,000 years; Berlin Wall and Mc Namara Line was 28 and 5 years respectively). The common point for the failure of Great Wall and Berlin Wall originated from the interior when the owners of these walls retreated in front of their opponents. In the case of Berlin Wall, it was, in fact, the barrier to progress and unification of the country, so the abolition of the wall in inevitable. The Great Wall was the failure against a more backward force when the defenders surrendered. And Mc Namara Line was quickly defeated when facing an opponent with a lower level of development but possessed an outstanding spirit and wisdom. In this case, it was the Vietnamese country that could prove that all protective walls could be overcome by human, however sophisticated and modern it was.

Fourthly, facing the fact that the world we are living is now under uncertainties caused by migration, ethnic conflicts; many countries have decided to build new protective wall in various forms such as anti-intrusion walls, modern missile defense system, trade barriers, firewall on the internet, and even the ties to ideology, ... When globalization and international integration become more vivid and the boundaries among countries gradually become vague; the appearance of such kind of walls are against the development. The country security is closely connected to the region and the world security, and for this reason, creating a barrier to protect ourselves is not the proper solution. What we should emphasize on is eliminating the reasons creating conflicts through collaboration for mutual development. The world would become secure if only there are no poverty, inequality and arms race.

\section{REFERENCES}

[1] Brush. P. (1996). The story behind Mc Namara line. Vietnam Magazine. No.2. Retrieved from https://msuweb.montclair.edu/ furrg/pbmcnamara.html

[2] Cuoc chien bi mat - Ho so luc luong biet quan nguy (Hieu.Vu, Trans) (2011). Hanoi Publishing house.

[3] Henry, S. (1971). Project CHECO Southeast Asia Report Igloo White. Retrieved from Scribd https://www.scribd.com/document/81662778/11-1-1971-IGLOO-WHIT E-January-1970-September-1971

[4] Hoang, C. Hieu. (2016). Doc Mieu - "The Magic Eye" of Mc Namara Electronic barrier". Military History Review, 6-2016, p. 59.

[5] Hoang, C. Hieu. (2017). More research on the Aim, Time and Place to set up Mc Namara's Electronic Line. Military History Review, 3-2017, p.83

[6] Krenz, E. (2010). Mua thu Duc 1989 (The Autum in Germany 1989) (Duc. Le, Trans). People's Public Security Press.

[7] Paullin, T. (2011). Chapter VI—"Numbed". Retrieved March 05, 2018, from

http://jtmcnaughtonfindawayout.blogspot.com/2011_01_01_archieved.h tml

[8] U.S Ground Strategy and Force Developments, 1965-1968. In The Pentagon Papers (1971). Retrieved from https://www.mtholyoke.edu/acad/intrel/pentagon4/pent7.html .

[9] Viet Nam Institute of Military History (1997). Hậu phương chiến tranh nhân dân Việt Nam (1945-1975). The People's Army Publishing House.

\section{Chi Hieu Hoang}

Place of birth: Quang Tri province, Vietnam; Date of birth: May 17, 1979. Mobile phone: 0914735779. He defended his doctoral thesis in 2012, specialized in Modern and Contemporary Vietnamese History at the University of Education, Hue University, Vietnam. In 2018, he was awarded the title of Associate Professor by the State Council for Professor Title of Vietnam.

Currently, he is a history lecturer at the Department of History, University of Education, Hue University, Vietnam. He has been working in this position since 2007 and obtained certain results. Some typical works can be listed such as the book: Demilitarized zone - The 17th parallel (1954-1967), publisher People's Army, Hanoi, 2017. ISBN 978-604-51-3147-3; Political struggle in Tri-Thien-Hue years after the Geneva Accords (1954-1956), Hue University project, Code DHH2011-03-03, 2011-2012 and various papers in journals. 